\title{
Drainage morphometric analysis for assessing form and processes of the watersheds of Pachamalai hills and its adjoinings, Central Tamil Nadu, India
}

\author{
A. Prabhakaran ${ }^{1}$ N. Jawahar Raj ${ }^{1}$
}

Received: 10 July 2017 / Accepted: 27 November 2017 / Published online: 2 February 2018

(c) The Author(s) 2018. This article is an open access publication

\begin{abstract}
The present study attempts to understand the form and geomorphic/hydrologic processes of the 20 watersheds of the Pachamalai hills and its adjoinings located in Tamil Nadu State of southern India from the analysis of its drainage morphometric characteristics. Survey of India's topographic sheets of 1:50,000 is the data source from which stream networks and watersheds of the study area were demarcated followed by the analysis of their morphometric characteristics using ArcGIS software. The results of the analysis formed the basis for deducing the form and processes of the watersheds of the study area. The form of the watersheds inferred from the analysis includes shape, length, slope steepness and length, degree of branching of streams, dissection and elongation of watersheds. The geomorphic/hydrologic processes inferred include denudation rate, potential energy, intensity of erosion, mean annual run off, mean discharge, discharge rate, rock resistivity and infiltration potential, amount of sediment transported, mean annual rainfall, rainfall intensity, lagtime, flash flood potential, flood discharge per unit area, sediment yield and speed of the water flow in the streams. The understanding of variations of form and processes mentioned can be used towards prioritizing the watersheds for development, management and conservation planning.
\end{abstract}

Keywords Drainage morphometry $\cdot$ Pachamalai hills $\cdot$ Form and processes

\section{Introduction}

Drainage basin or a watershed refers to the entire area providing runoff to and sustaining part or all of the streamflow of, the main stream and its tributaries. Quantitative analysis of drainage network within a basin or watershed can throw light upon the form and predominant processes in them, a knowledge which is indispensible for planning relating to watershed management, floods, soil erosion, mass movement, neotectonic activities, surface and groundwater, derivation of hydrographs and understanding discharge characteristics of ungauged stream, ecology, etc. The description of drainage network within a basin which was purely qualitative was transferred into a rigorous quantitative science capable of providing numerical data of practical value by Horton

\section{A. Prabhakaran}

geoprabha15@gmail.com

1 Department of Geology, National College, Tiruchirappalli 620001, Tamil Nadu, India
(1932, 1945). The works were supplemented by Langbein (1947), and later, developed in detail by Strahler (1952), Miller (1953), Leopold and Miller (1956), Schumm (1956), Morisawa (1959), Shreve (1966), Scheidegger (1967), Doornkamp (1968), Chorley (1969), Gregory and Walling (1973), Gardiner (1975) and Zavoianu (1985), and others. A number of related studies have been carried out since then for which topographic maps and data obtained from field work have been the source. In recent times especially since the last decade, the advancements made in Remote Sensing and Geographical Information System (GIS) technology has taken the study to the next level. In the present study, an attempt has been made to understand the form and processes of the watersheds of the Pachamalai hills and its adjoinings located in the central Tamil Nadu State of southern India. The inhabitants of the study area, most of whom are tribals depend upon the streams that flow through the study area for catering their water needs. Besides this, the rain water that flows through these streams is the major source of water flow for the important rivers that flow through the adjoining foot hills and plains of the region such as Swetha Nadhi, 
Chinnar, Aiyar and Marudhaiyar, and the region depends on these rivers for catering their water needs of the people, including agriculture the major occupation of the region. In other words, the livelihood of the inhabitants of Pachamalai and the adjoining plains of the region depends on the water that drains the watersheds of the study area. The study area which is rich in biodiversity (Geetha Rani 2010; Velmani 1998) has been ruthlessly overexploited for its rich resources for several decades. The overexploitation of this biodiversity rich area and the unscientific agricultural practices (Pragasan 2014; Velmani 1999; Mathew 1981) have resulted in accelerated soil erosion rates, increased flood incidences, reduced agricultural productivity, and, biodiversity of the hills. All these problems calls for effective planning towards ensuring sustainability of the water and other resources of the Pachamalai hills and its adjoinings on watershed basis for which the results from the present study can provide useful inputs.

\section{Study area and its geology}

The study area, the Pachamalai hills and its adjoinings, covers an areal extent of $868.01 \mathrm{sq} . \mathrm{km}$ and is located in Central Tamil Nadu State of southern India (Fig. 1). It is located between north latitudes $11^{\circ} 7^{\prime} 47^{\prime \prime}-11^{\circ} 29^{\prime} 26^{\prime \prime}$ and east longitudes $78^{\circ} 24^{\prime} 22^{\prime \prime}-78^{\circ} 51^{\prime} 10^{\prime \prime}$. Most parts of the study area, especially the northern and southern parts are confined to Salem and Tiruchirappalli Districts of Tamil Nadu State (Fig. 2). Smaller portions of the study area, especially the eastern and south eastern parts fall in Perambalur District while the western part falls in Namakkal District of the State. Information relating to relief and slope deduced from the Digital Elevation Model (DEM), generated from SRTM satellite data (Figs. 3, 4, respectively) reveals that in most of the study area (about 66\%) the elevation is less than $400 \mathrm{~m}$, and the slope ranges from nearly level category to moderately steep to steep category in most of the study area $(70 \%)$. The study area experiences a semi-arid climate with dry and cold winter and hot and dry summer. In the Pachamalai hills, the maximum temperature ranges between 23 and $31^{\circ} \mathrm{C}$ while the minimum temperature ranges between
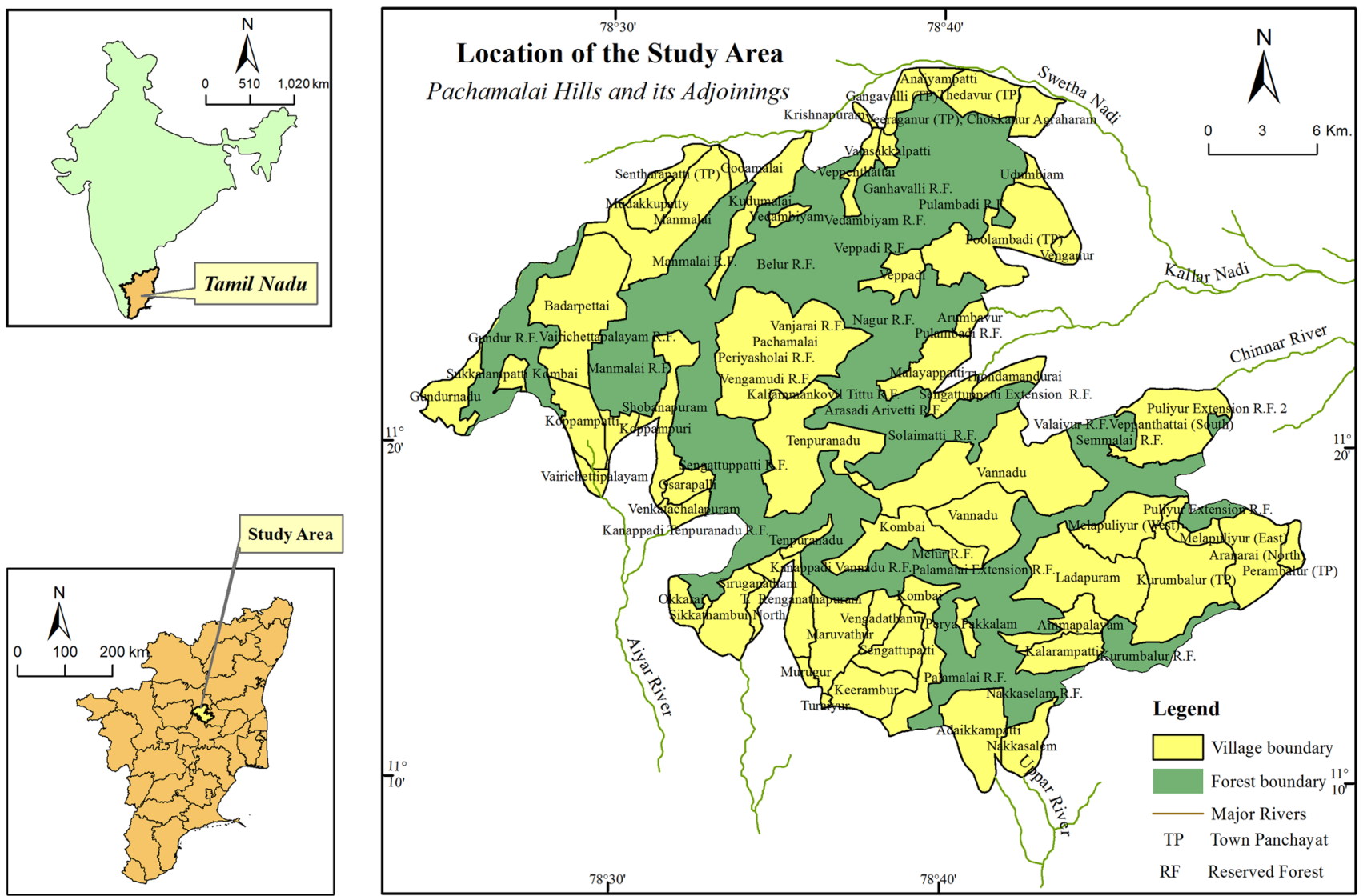

Fig. 1 Study area 


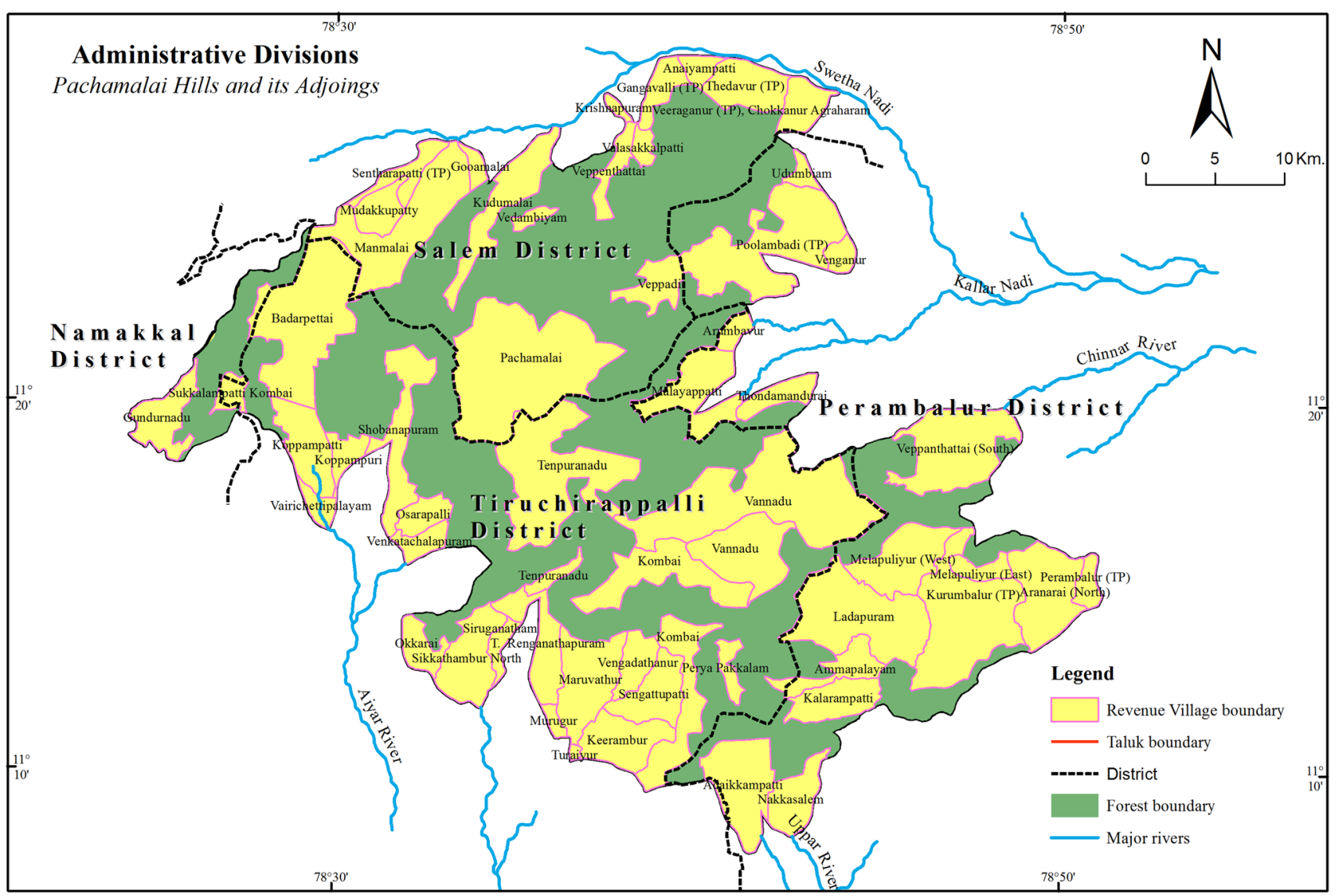

Fig. 2 Administrative divisions

12 and $18{ }^{\circ} \mathrm{C}$, (http://agritech.tnau.ac.in/agriculture/agri_ agrometeorology_croppingpattern_highaltitudezone.html). The study area receives bulk of its annual rainfall during the months of September, October and November, though considerable rainfall occurs during the months of June and August.

Geologically, the study area forms part of the Southern Granulitic Terrain (SGT) of Tamil Nadu State which has experienced multiple episodes of crustal deformation during and after its formation (Drury and Holt 1980; Ramasamy et al. 1999; Chetty and Bhaskara Rao 2006) because of which the rocks are highly deformed and metamorphosed to granulite facies. The most pervasive of these deformation events has been the 550 Ma Pan-African granulite facies event (Unnikrishnan et al. 1995; Jayananda et al. 1995; Bartlett et al. 1995). Information relating to the rock types of the study area obtained from the geology map published by the Geological Survey of India (GSI) in the year 2014 reveals that the study area comprises predominantly of the rocks of Charnockite Group (mostly charnockites intruded by ultrabasic rocks and granites, and pyroxene granulites) and Bhavani Group (fissile hornblende biotite gneiss and basic dykes) of Archaean and Archaean to Proterozoic age, respectively (Fig. 5). The Charnockite Group rocks of the study area are of igneous/volcanic parentage derivatives and the pyroxene granulites in specific are considered to represent mafic volcanics (Srinivasan 2006). The granulitic facies metamorphism that occurred in the study area along with other parts of the State during the Late Archaean-Early Proterozoic Periods has resulted in the formation of these charnockites and concomitant anatexis of earlier rocks (Srinivasan 2006).

Charnockites, the predominant rock type of the study area occupies about $93 \%$ of the study area. The mineral assemblages of this rock in the study area are orthopyroxene + quartz + K-feldspars + biotite \pm garnet. Geochemically the charnockites of this region has been characterized as Tonalite and the charnockitic magma is found to have originated from a middle crustal region due to crustal recycling and is calc alkaline in nature. Pyroxene granulites found in the study area occur in the form linear bands trending in an almost NE-SW direction confining to the northern part of the study area, especially in the Gangavalli, Pulambadi and Vedambiyam Reserved Forests. The mineral assemblage of this rock includes quartz + clinopyroxene + orthopyroxene and k-feldspar. Hornblende

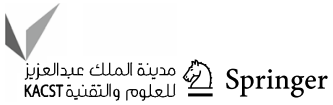




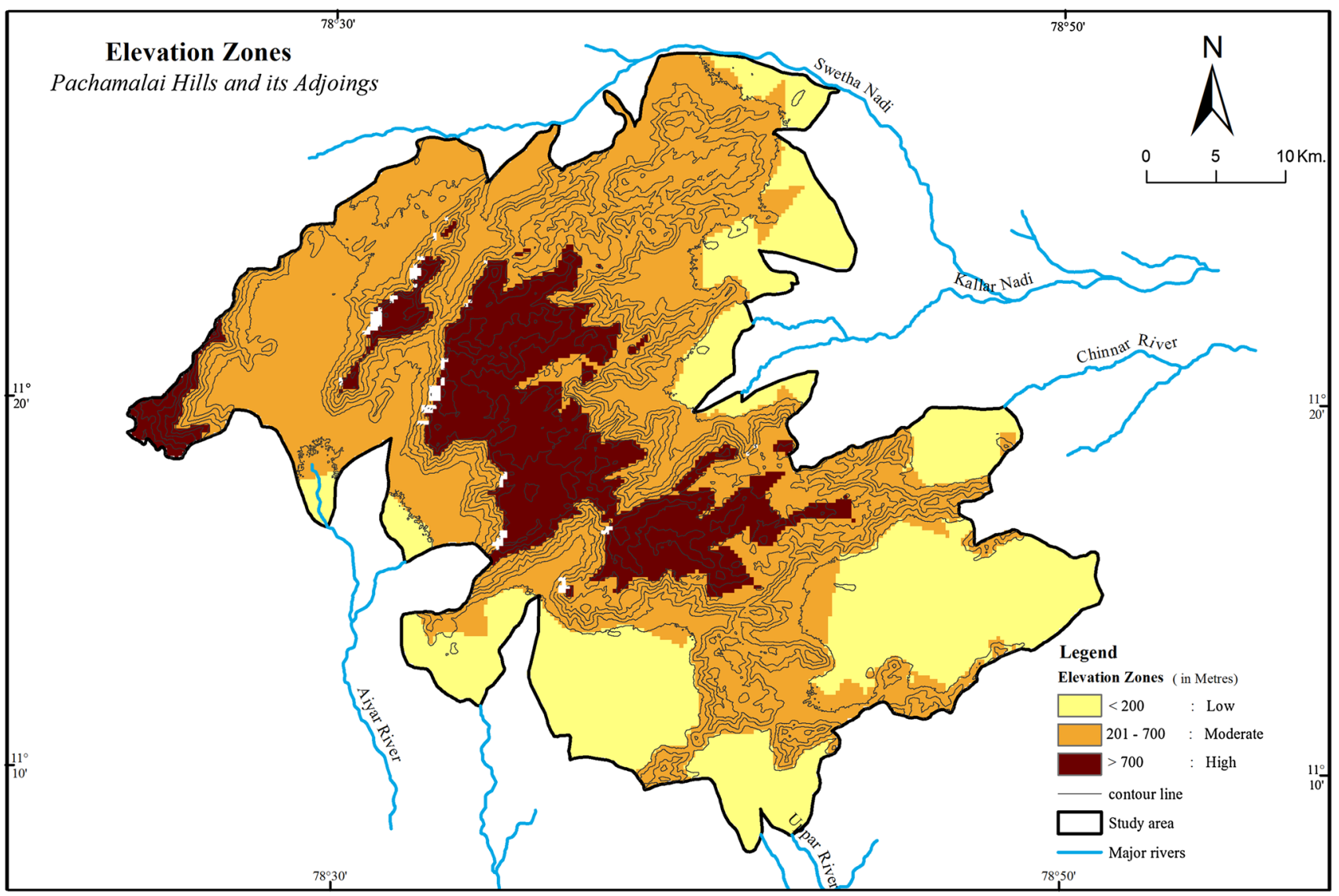

Fig. 3 Rock types

biotite gneiss occupies about $2.6 \%$ of the study area and is confined to the foot hills especially on the eastern and south eastern parts. The mineral assemblage of this rock is quartz-hornblende-biotite-K-feldspar-plagioclase. Granite, basic dykes, ultrabasics and garnetiferous gabbro are the other rock types present in the study area but they are of minor areal extent. Of these rocks, granites in the study area are seen with charnockites as enclaves, and are confined to the northern part especially to the Vedambiyam and Pulambadi Reserved Forests. These small plutons were emplaced as culmination of migmatisation that occurred in the area during the Late Archaean-Early Proterozoic Periods. Basic dykes of the study area are seen transecting the charnockites and are exposed in three locations. One of them occurs in the northern part of the study area (near Vedambiyam) trending in a NNE-SSW direction while the other two are found in the eastern part of the study area (near Nagur and Sikkadu villages) trending in ENE-WSW to nearly E-W direction. A small patch of ultrabasic rocks occurs in the western part of the study area within the Sengattupatti Reserved Forest. The strike direction of the foliation of the major rock type of the study area, the charnockites, is predominantly NE-SW. Two prominent synform structures are found on the western part of the study area, one of which is in the Periyasolai Reserved Forest and the other in the north eastern side of Sengattupatti Reserved Forests. A prominent antiform structure is found in the south eastern side of the Sengattupatti Reserved Forests. Two prominent NNE-SSW trending shear zones pass through the Manmalai Reserved Forest in the north western part of the study area.

\section{Methodology}

For the present study, relevant literature was thoroughly studied to enrich and update the knowledge in the subject. This was followed by the mapping of drainage network (Fig. 6) and delineation of the watersheds (Fig. 7) of the study area from the Survey of India's topographic sheets of 1:50,000 scale. For identity purpose, either the name of the stream that flows through the watershed or the name of the major settlement/Reserved Forests within the watershed were assigned to the each of the 20 watersheds of the study area. Later, the stream networks within each of the watersheds were digitized using ArcGIS. The widely used Strahler's method of stream ordering was followed for ordering 


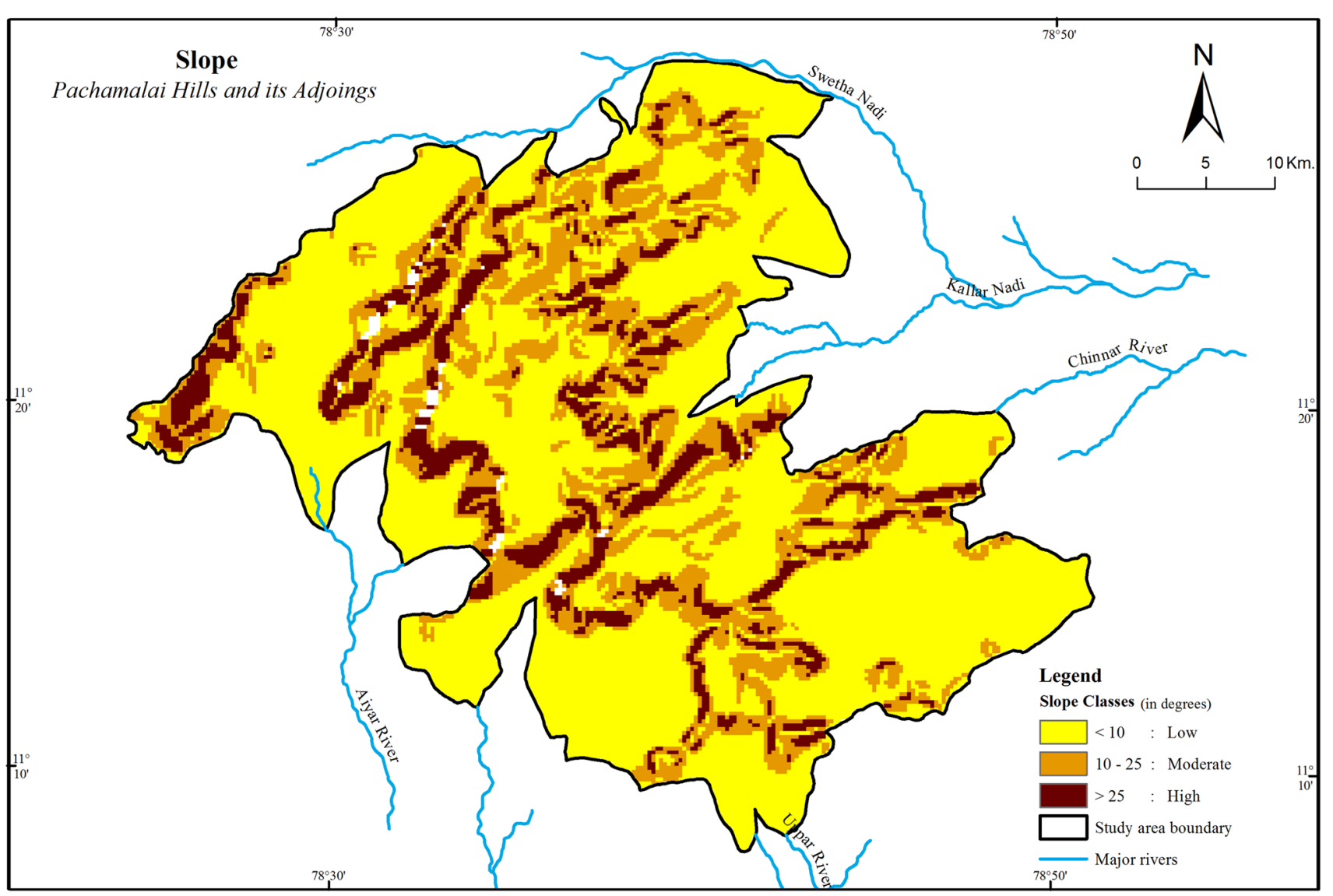

Fig. 4 Elevation zones

the streams of the study area. ArcGIS software was utilized to calculate measures such as number of streams, length of streams, area and length of watersheds, and elevation ranges and were made use to estimate a number of parameters relating to linear (bifurcation ratio, length ratio), areal (drainage density, stream frequency, shape, length of overland flow, etc.) and relief aspects (relief, relative relief, ruggedness number, etc.) in each of the watersheds of the study area. These estimations were made use to understand the form and dominant processes within each of the watersheds of the study area.

\section{Results and discussion}

\section{Linear aspects}

Linear aspects of the basins are related to the channel patterns of the drainage network wherein the topological characteristics of the stream segments in terms of open links of the network system (streams) are analysed. The study of linear aspect includes the analysis of stream order, stream number, bifurcation ratio, stream lengths and length ratio.
These parameters were estimated for all the watersheds of the study area and are shown in Table 1(a)-(t) and consolidated in Table 2. The results of their analysis and the inferences drawn are discussed in the following section.

\section{Stream order}

Stream ordering, the first step in morphometric analysis of drainage basin analysis, is a measure of the position of a stream in the hierarchy of tributaries (Strahler 1964). As mentioned earlier, for the present study the widely followed Strahler's method of stream ordering has been adopted towards ordering the streams of the drainage network in all the watersheds of the study area. Such ordering of the streams is an essential input towards estimating several other drainage morphometric parameters considered for the present study. Besides this, it has been used to find out the maximum stream order (the stream segment of the highest order) within each watershed. This maximum stream order, viz., the trunk stream, through which all the discharge of a watershed finds its outlet, has been used to designate each watershed of the study area. Among the watersheds of the study area, the maximum stream order 


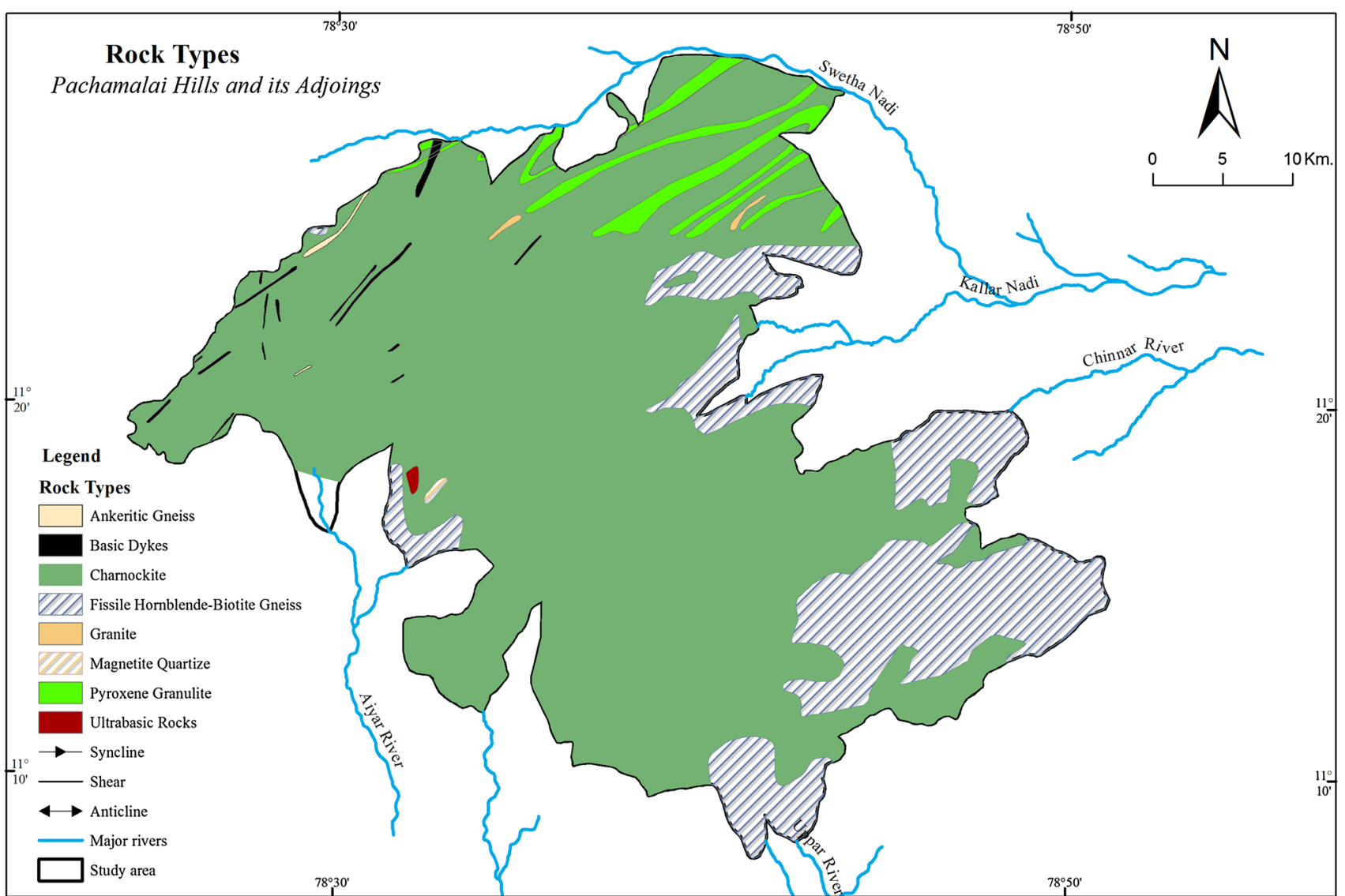

Fig. 5 Slope

ranges from third order to sixth order. A majority of the watersheds $(55 \%)$ are fourth order watersheds and these include Sendarapatti, Kallar, Belur, Pulambadi, Periyakaruppu Odai, Kalungi, Solaimatti, Silaiyur, Chinnar, Nakkaselam and Turaiyur Kalathur watersheds, followed by fifth order watersheds (35\%) which includes Gangavalli, Kottarakkannu, Sengattuppatti, Maruvattur, Kannapadi, Shobanapuram and Thalugai watersheds. Koneri watershed and Valiyur watershed are the only sixth order and third order watershed, respectively, in the study area.

Apart from its use in designating watersheds, the maximum stream order of the watershed can also be used to designate the trunk stream of the watershed. In general, streams up to third order are designated as headwater streams, from fourth to sixth order they are designated as medium streams, and stream orders greater than sixth order are designated as river (http://geography.about.com/ od/physicalgeography/a/streamorder.htm). The maximum stream order in almost all the watersheds of the study area, with the exception of Valaiyur watershed, ranges from fourth to sixth order. This implies that the trunk stream in all the watersheds of the study area is a medium stream; in case of Valaiyur watershed, the trunk stream is a third order stream, and hence it is a headwater stream.

\section{Stream number}

Stream number of a watershed refers to the number of stream segments within a watershed. Estimations regarding orderwise stream number and total number of streams in each watershed were made and their analysis shows the existence of wide variation in the total number of streams among the watersheds of the study area ranging from 30 (in Valaiyur watershed) to 458 (Koneri watershed). The number of stream segments decreases with increasing stream order in all the watersheds of the study area. Among the various stream orders, the proportion of first-order streams, constitute bulk of the total number of streams in all the watersheds, ranging from $68.89 \%$ (in Thuraiyur Kalathur watershed) to $82.05 \%$ (Kalungi watershed). It is observed that the lower order streams, viz., both first and second-order streams constitute most of the streams in each watershed and their proportion ranges from $90.59 \%$ (in Maruvattur watershed) to $96.67 \%$ (Valaiyur watershed) of the total streams of the respective 


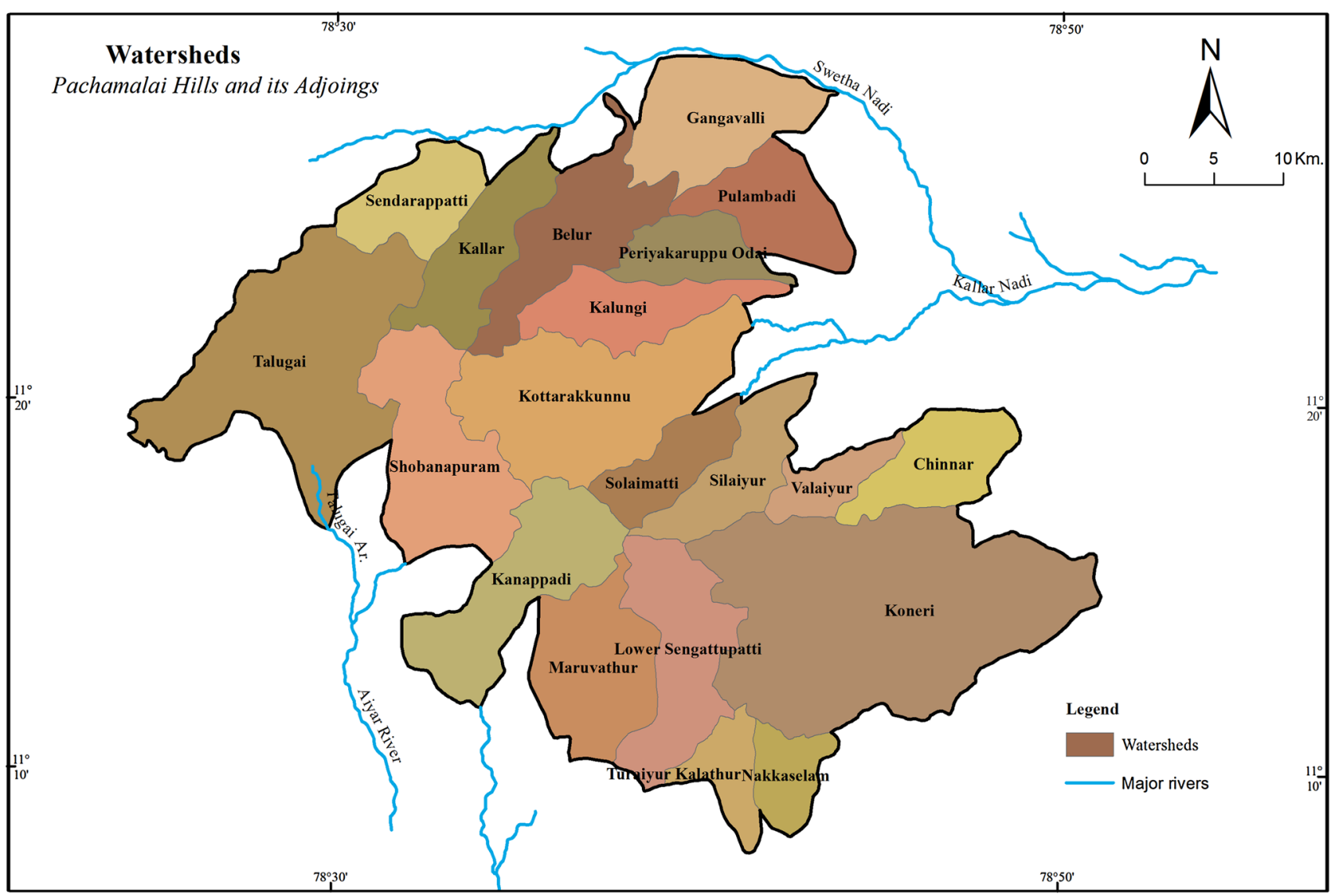

Fig. 6 Watersheds

watersheds. In the study area, the lower order streams are relatively greater in proportion ( $>95 \%$ ) in Valaiyur, Belur, Kalungi, Solaimatti and Kallar watersheds which reflects the steeper slopes and quicker water flow in these watersheds. The lower order streams are relatively lesser $(\leq 92 \%)$ in Nakkasalem, Maruvattur, Thuraiyur Kalathur and Talugai watersheds, and this reflects the relatively lesser slope steepness and less quick stream flows.

\section{Bifurcation ratio}

The bifurcation ratio $\left(R_{\mathrm{b}}\right)$ refers to the ratio of the number of streams of a given order to the number of streams of the next higher order, and it is a measure of the amount of branching in the stream network (Doornkamp and King 1971) within a watershed. Lower the mean bifurcation ratio, greater the branching in the stream network within a watershed and vice-versa. Bifurcation ratio for the various stream orders within a watershed, and the mean $R_{\mathrm{b}}$ value for each watershed were estimated, and their analysis shows that it distinctly varies among various orders in each watershed, reflecting the variations in local physiography and geological conditions within each watershed. The mean $R_{\mathrm{b}}$ value of the watersheds of the study area ranges from 2.84 (for Maruvattur watershed) to 5.00 (Belur watershed). Strahler (1957) has observed that the mean $R_{\mathrm{b}}$ value ranges from 2 to 5 in watersheds with well developed drainage network. As the mean $R_{\mathrm{b}}$ values of all the watersheds of the study area are within this range, it can be inferred that the drainage network in all the watersheds of the study area are well developed.

Apart from serving as an indices to infer the degree of branching of stream network within a watershed, it can also throw light upon the shape of the watersheds; high $R_{\mathrm{b}}$ values reflect elongated shape whereas low values reflect circular or rotund shape (Chow 1964). Assuming precipitation and other controls to be the same, elongate watersheds yield low but extended peak flow whereas rotund watersheds produce sharp peak (Chow 1964; Chorley 1969). In short, the lower the mean $R_{\mathrm{b}}$ of the watershed, the greater the probability of flash flood. In the study area the mean $R_{\mathrm{b}}$ is relatively lesser $(\leq 3.5)$ in Maruvattur, Thuraiyur Kalathur, Nakkasalem, Gangavalli, Koneri, Kanappadi and Sengattupatti watersheds, and relatively high (> 4.5) in Belur, Valaiyur, Kallar and Kalungi watersheds. In rest of the other watersheds it is moderate (3.5-4.5). This imples the relatively greater degree of branching, lesser elongation, and higher 


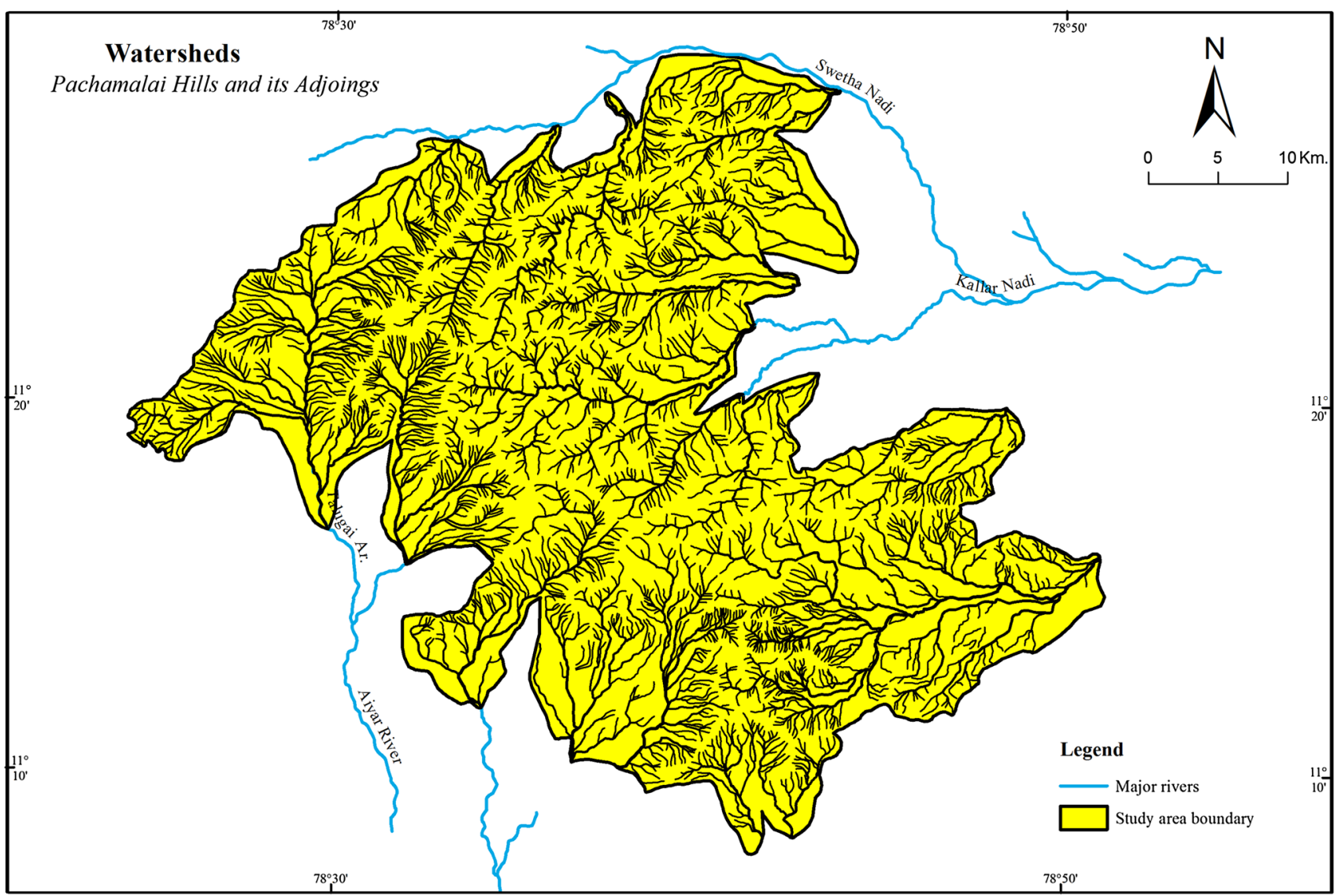

Fig. 7 Drainages

flash flood potential of Maruvattur, Thuraiyur Kalathur, Nakkasalem, Gangavalli, Koneri, Kanappadi and Sengattupatti watersheds, and lesser degree of branching, greater elongation and lesser flash flood potential of Belur, Valaiyur, Kallar and Kalungi watersheds.

\section{Stream length}

The length of a stream is the distance measured along the stream channel from the source to a given point or to the outlet. This distance was estimated for all stream orders within a watershed and they were added together to find out the total stream length of the watershed. This measure is an essential input for computing various other morphometric parameters such as mean stream length, drainage density, length of overland flow, etc. Estimation of total stream length for the watersheds of the study area shows that among the watersheds of the study area the total stream length varies from $28.08 \mathrm{~km}$ (in Valaiyur watershed) to $412.53 \mathrm{~km}$ (Koneri watershed). The total length of streams is relatively lesser $(\leq 70 \mathrm{~km})$ in Valaiyur, Nakkaselam, Thuraiyur Kalathur, Silaiyur, Solaimatti, Pulambadi and Periyakaruppu Odai watersheds, and is relatively higher $(>170 \mathrm{~km})$ in Koneri,
Thalugai, Shobanapuram and Kottarakkannu watersheds. In rest of the watersheds it is moderate $(70-170 \mathrm{~km})$. As the total stream length is directly related with the mean annual run off (Morisawa 1962), it can be inferred that the mean annual run off would be higher in Koneri, Thalugai, Shobanapuram and Kottarakkannu watersheds on account of their high total stream lengths, and relatively lower in Valaiyur, Nakkaselam, Thuraiyur Kalathur, Silaiyur, Solaimatti, Pulambadi and Periyakaruppu Odai watersheds on account of their low total stream lengths. In rest of the other watersheds, the mean annual run off is likely to be moderate on account of their moderate total stream lengths.

\section{Mean stream length}

The mean stream length is a dimensional property, revealing the characteristic size of the components of a drainage network and its contributing basin surface (Strahler 1964). Stream order-wise mean length in each watershed was obtained by dividing the total length of streams of a particular order by the total number of stream segments of the order. In general, it is observed that the mean stream length increases with the stream order. Only in five watersheds viz., 
Table 1 Watershed-wise linear aspects (a)-(t)

Stream order Stream number

Stream num- Bifurcation ratio ber $(\%)$

a. Sendarapatti watershed

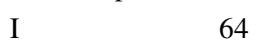

II 17

III 5

IV 1

87

b. Kallar watershed

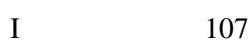

II 23

III 5

IV

5
1

136

c. Belur watershed$$
\text { I } 125
$$

II 25

III 5

IV

1
156

d. Gangavalli watershed

I
II
III
IV
V

91
24
5
2
1
123

e. Pulambadi watershed

$\begin{array}{lr}\text { I } & 45 \\ \text { II } & 10 \\ \text { III } & 3 \\ \text { IV } & 1 \\ & 59\end{array}$

f. Periyakaruppu Odai watershed

$\begin{array}{lr}\text { I } & 54 \\ \text { II } & 15 \\ \text { III } & 4 \\ \text { IV } & 1 \\ & 74\end{array}$

g. Kalungi watershed

I
II
III
IV

96

16

4

117

h. Kottarakunnu watershed

$\begin{array}{lr}\text { I } & 183 \\ \text { II } & 40 \\ \text { III } & 13 \\ \text { IV } \\ \text { V }\end{array}$

$\begin{array}{rr}73.56 & \\ 19.54 & 3.76 \\ 5.75 & 3.40 \\ 1.15 & 5.00 \\ 100.00 & 4.05\end{array}$

78.68

16.91

3.68

0.74

100.00

80.13

16.03

3.21

0.64

100.00

4.65

4.60

5.00

4.75

73.98

19.51

$\begin{array}{ll}19.51 & 3.79\end{array}$

$4.07 \quad 4.80$

$1.63 \quad 2.50$

$0.81 \quad 2.00$

$100.00 \quad 3.27$

76.27

16.95

5.08

1.69

100.00

72.97

20.27

5.41

3.60

1.35

3.75

100.00

4.00

3.78

82.05

13.68

3.42

0.85

100.00

76.25

16.67

5.42

1.25

0.42

4.58

4.33

3.00
39.31

20.66

7.10

5.41

72.48

64.98

18.55

4.76

11.12

99.41

65.46

18.09

9.17

16.32

109.04

65.08

23.02

14.59

12.15

0.51

115.35

28.57

14.73

10.73

4.93

58.96

35.95

11.63

7.39

6.94

61.91

55.25

13.73

8.66

10.46

88.10

111.56

30.42

26.50

10.84

7.54

54.24
28.50
9.80
7.46
100.00

65.37

18.66

4.79

11.19

100.00

60.03

16.59

8.41

14.97

100.00

56.42

19.96

12.65

10.53

0.44

100.00

48.46

24.98

18.20

8.36

100.00

58.07

18.79

11.94

11.21

100.00

62.71

15.58

9.83

11.87

100.00

59.70
16.28
14.18
5.80
4.04

\subsection{1}

1.22

1.42

5.41

0.86

0.26

0.54

0.61

0.81

0.95

11.12

0.75

0.85

0.09

0.56

0.52

0.72

1.83

0.72

0.39

0.11

0.41

0.72

0.96

2.92

6.08

0.51

0.75

0.33

0.48

11.91

3.37

0.63

1.47

0.43

3.58

0.41

4.93

0.73

0.52

0.67

0.78

0.86

1.85

0.42

6.94

0.27

0.51

0.58

0.86

0.67

2.17

0.40

10.46

0.21

0.42

61

0.76

0.80

2.04

0.37

3.61

0.56

7.54

0.48 
Table 1 (continued)

\begin{tabular}{|c|c|c|c|c|c|c|c|}
\hline Stream order & Stream number & $\begin{array}{l}\text { Stream num- } \\
\text { ber }(\%)\end{array}$ & Bifurcation ratio & Stream length & Stream length (\%) & $\begin{array}{l}\text { Mean stream } \\
\text { length }\end{array}$ & Length ratio \\
\hline & 240 & 100.00 & 3.75 & 186.86 & 100.00 & & 0.55 \\
\hline \multicolumn{8}{|c|}{ i. Solaimatti watershed } \\
\hline $\mathrm{I}$ & 55 & 78.57 & & 42.58 & 71.45 & 0.77 & \\
\hline II & 12 & 17.14 & 4.58 & 7.21 & 12.10 & 0.60 & 1.29 \\
\hline III & 2 & 2.86 & 6.00 & 2.93 & 4.92 & 1.47 & 0.41 \\
\hline \multirow[t]{2}{*}{ IV } & 1 & 1.43 & 2.00 & 6.87 & 11.53 & 6.87 & 0.21 \\
\hline & 70 & 100.00 & 4.19 & 59.59 & 100.00 & & 0.64 \\
\hline \multicolumn{8}{|c|}{ j. Silaiyur watershed } \\
\hline I & 49 & 81.67 & & 36.04 & 60.49 & 0.74 & \\
\hline II & 7 & 11.67 & 7.00 & 11.58 & 19.44 & 1.65 & 0.44 \\
\hline III & 3 & 5.00 & 2.33 & 3.54 & 5.94 & 1.18 & 1.40 \\
\hline \multirow[t]{2}{*}{ IV } & 1 & 1.67 & 3.00 & 8.42 & 14.13 & 8.42 & 0.14 \\
\hline & 60 & 100.00 & 4.11 & 59.58 & 100.00 & & 0.66 \\
\hline \multicolumn{8}{|c|}{ k. Valaiyur watershed } \\
\hline I & 24 & 80.00 & & 16.84 & 59.97 & 0.70 & \\
\hline II & 5 & 16.67 & 4.80 & 4.93 & 17.56 & 0.99 & 0.71 \\
\hline \multirow[t]{2}{*}{ III } & 1 & 3.33 & 5.00 & 6.31 & 22.47 & 6.31 & 0.16 \\
\hline & 30 & 100.00 & 4.90 & 28.08 & 100.00 & & 0.43 \\
\hline \multicolumn{8}{|c|}{ 1. Chinnar watershed } \\
\hline I & 57 & 75.00 & & 40.47 & 55.59 & 0.71 & \\
\hline II & 14 & 18.42 & 4.07 & 17.00 & 23.35 & 1.21 & 0.58 \\
\hline III & 4 & 5.26 & 3.50 & 12.51 & 17.18 & 3.13 & 0.39 \\
\hline \multirow[t]{2}{*}{ IV } & 1 & 1.32 & 4.00 & 2.82 & 3.87 & 2.82 & 1.11 \\
\hline & 76 & 100.00 & 3.86 & 72.80 & 100.00 & & 0.69 \\
\hline \multicolumn{8}{|c|}{ m. Koneri watershed } \\
\hline I & 338 & 73.80 & & 230.89 & 55.97 & 0.68 & \\
\hline II & 85 & 18.56 & 3.98 & 71.97 & 17.45 & 0.85 & 0.81 \\
\hline III & 24 & 5.24 & 3.54 & 54.78 & 13.28 & 2.28 & 0.37 \\
\hline IV & 8 & 1.75 & 3.00 & 38.84 & 9.42 & 4.86 & 0.47 \\
\hline $\mathrm{V}$ & 2 & 0.44 & 4.00 & 13.15 & 3.19 & 6.58 & 0.74 \\
\hline \multirow[t]{2}{*}{ VI } & 1 & 0.22 & 2.00 & 2.9 & 0.70 & 2.90 & 2.27 \\
\hline & 458 & 100.00 & 3.30 & 412.53 & 100.00 & & 0.93 \\
\hline \multicolumn{8}{|c|}{ n. Nakkasalem watershed } \\
\hline I & 33 & 70.21 & & 22.49 & 57.61 & 0.68 & \\
\hline II & 10 & 21.28 & 3.30 & 7.1 & 18.19 & 0.71 & 0.96 \\
\hline III & 3 & 6.38 & 3.33 & 6.07 & 15.55 & 2.02 & 0.35 \\
\hline \multirow[t]{2}{*}{ IV } & 1 & 2.13 & 3.00 & 3.38 & 8.66 & 3.38 & 0.60 \\
\hline & 47 & 100.00 & 3.21 & 39.04 & 100.00 & & 0.64 \\
\hline \multicolumn{8}{|c|}{ o. Turaiyur Kalathur watershed } \\
\hline I & 31 & 68.89 & & 21.20 & 50.99 & 0.68 & \\
\hline II & 10 & 22.22 & 3.10 & 13.60 & 32.71 & 1.36 & 0.50 \\
\hline III & 3 & 6.67 & 3.33 & 2.78 & 6.69 & 0.93 & 1.47 \\
\hline \multirow[t]{2}{*}{ IV } & 1 & 2.22 & 3.00 & 4.00 & 9.62 & 4.00 & 0.23 \\
\hline & 45 & 100.00 & 3.14 & 41.58 & 100.00 & & 0.73 \\
\hline \multicolumn{8}{|c|}{ p. Sengattuppatti watershed } \\
\hline I & 122 & 75.31 & & 85.27 & 60.24 & 0.70 & \\
\hline II & 29 & 17.90 & 4.21 & 27.29 & 19.28 & 0.94 & 0.74 \\
\hline III & 8 & 4.94 & 3.63 & 20.56 & 14.53 & 2.57 & 0.37 \\
\hline IV & 2 & 1.23 & 4.00 & 3.01 & 2.13 & 1.51 & 1.71 \\
\hline
\end{tabular}


Table 1 (continued)

\begin{tabular}{|c|c|c|c|c|c|c|c|}
\hline Stream order & Stream number & $\begin{array}{l}\text { Stream num- } \\
\text { ber }(\%)\end{array}$ & Bifurcation ratio & Stream length & Stream length $(\%)$ & $\begin{array}{l}\text { Mean stream } \\
\text { length }\end{array}$ & Length ratio \\
\hline \multirow[t]{2}{*}{$\mathrm{V}$} & 1 & 0.62 & 2.00 & 5.41 & 3.82 & 5.41 & 0.28 \\
\hline & 162 & 100.00 & 3.46 & 141.54 & 100.00 & & 0.77 \\
\hline \multicolumn{8}{|c|}{ q. Maruvattur watershed } \\
\hline I & 59 & 69.41 & & 49.33 & 50.94 & 0.84 & \\
\hline II & 18 & 21.18 & 3.28 & 24.75 & 25.56 & 1.38 & 0.61 \\
\hline III & 5 & 5.88 & 3.60 & 14.95 & 15.44 & 2.99 & 0.46 \\
\hline IV & 2 & 2.35 & 2.50 & 6.02 & 6.22 & 3.01 & 0.99 \\
\hline \multirow[t]{2}{*}{$\mathrm{V}$} & 1 & 1.18 & 2.00 & 1.78 & 1.84 & 1.78 & 1.69 \\
\hline & 85 & 100.00 & 2.84 & 96.83 & 100.00 & & 0.94 \\
\hline \multicolumn{8}{|c|}{ r. Kanappadi watershed } \\
\hline $\mathrm{I}$ & 110 & 72.85 & & 78.68 & 59.63 & 0.72 & \\
\hline II & 31 & 20.53 & 3.55 & 27.76 & 21.04 & 0.90 & 0.80 \\
\hline III & 7 & 4.64 & 4.43 & 12.93 & 9.80 & 1.85 & 0.48 \\
\hline IV & 2 & 1.32 & 3.50 & 8.80 & 6.67 & 4.40 & 0.42 \\
\hline \multirow[t]{2}{*}{$\mathrm{V}$} & 1 & 0.66 & 2.00 & 3.77 & 2.86 & 3.77 & 1.17 \\
\hline & 151 & 100.00 & 3.37 & 131.94 & 100.00 & & 0.72 \\
\hline \multicolumn{8}{|c|}{ s. Shobanapuram watershed } \\
\hline I & 167 & 74.89 & & 122.48 & 62.77 & 0.73 & \\
\hline II & 41 & 18.39 & 4.07 & 38.49 & 19.73 & 0.94 & 0.78 \\
\hline III & 10 & 4.48 & 4.10 & 20.37 & 10.44 & 2.04 & 0.46 \\
\hline IV & 4 & 1.79 & 2.50 & 4.93 & 2.53 & 1.23 & 1.65 \\
\hline \multirow[t]{2}{*}{$\mathrm{V}$} & 1 & 0.45 & 4.00 & 8.86 & 4.54 & 8.86 & 0.14 \\
\hline & 223 & 100.00 & 3.67 & 195.13 & 100.00 & & 0.76 \\
\hline \multicolumn{8}{|c|}{ t. Talugai watershed } \\
\hline I & 251 & 72.54 & & 174.94 & 56.69 & 0.70 & \\
\hline II & 66 & 19.08 & 3.80 & 73.96 & 23.97 & 1.12 & 0.62 \\
\hline III & 20 & 5.78 & 3.30 & 31.43 & 10.18 & 1.57 & 0.71 \\
\hline IV & 8 & 2.31 & 2.50 & 15.97 & 5.17 & 2.00 & 0.79 \\
\hline \multirow[t]{2}{*}{$\mathrm{V}$} & 1 & 0.29 & 8.00 & 12.30 & 3.99 & 12.30 & 0.16 \\
\hline & 346 & 100.00 & 4.40 & 308.60 & 100.00 & & 0.57 \\
\hline
\end{tabular}

Thuraiyur Kalathur, Shobanapuram, Solaimatti, Silaiyur and Sengattupatti watersheds this trend is anomalously absent. In case of Shobanapuram, Silaiyur, Thuraiyur Kalathur and Sengattupatti watersheds, III order mean stream length is abnormally lower than the II order mean stream length, and, in case of Solaimatti watershed the II order mean stream length is abnormally more than I order mean stream length. This anomaly can be attributed to the distinct variations in slope and topography in these watersheds, and such anomaly has been reported by studies (Rudraiah et al. 2008; Chopra et al. 2005; Vittala et al. 2004), conducted in other areas also.

Among the watersheds of the study area the mean length of first-order streams ranges from $0.52 \mathrm{~km}$ (for Belur watershed) to $0.84 \mathrm{~km}$ (Maruvattur watershed). It is shorter $(<0.60 \mathrm{~km})$ in Belur and Kalungi watersheds, and longer $(>0.75 \mathrm{~km})$ in Maruvattur and Solaimatti watersheds. In other watersheds it is moderate $(0.60-0.75 \mathrm{~km})$. In case of second-order streams the mean length ranges from $0.60 \mathrm{~km}$ (Solaimatti watershed) to $1.65 \mathrm{~km}$ (Silaiyur watershed). It is found to be shorter $(<0.75 \mathrm{~km})$ in Solaimatti, Nakkaselam and Belur watersheds and longer $(>1.25 \mathrm{~km})$ in Silaiyur, Pulambadi, Maruvattur and Thuraiyur Kalathur watersheds. In other watersheds it is moderate $(>0.75-1.25 \mathrm{~km})$.

\section{Length ratio}

It is the ratio of the mean length of streams of one order to that of the next higher order. It tends to be constant throughout the successive orders of a watershed (Horton 1945). Estimation of length ratio and the mean length ratio for the various stream orders of the watersheds and for each watershed were made. Variations in length ratio exist between successive stream orders in all the watersheds of the study 
Table 2 Linear aspects of the watersheds (consolidated)

\begin{tabular}{llrrlllll}
\hline Sl. no & Watershed name & S. length & T.S. no.* & I ord. str. & II ord. st. & Lower o. st & $R_{\mathrm{b}}{ }^{*}$ & $R_{\mathrm{l}}{ }^{*}$ \\
\hline 1. & Sendarapatti & 72.48 & 87 & 73.56 & 19.54 & 93.10 & 4.05 & 0.54 \\
2. & Kallar & 99.41 & 136 & 76.68 & 16.91 & 95.59 & 4.75 & 0.56 \\
3. & Belur & 109.04 & 156 & 80.13 & 16.03 & 96.16 & 5.00 & 0.41 \\
4. & Gangavalli & 115.35 & 123 & 73.98 & 19.51 & 93.49 & 3.27 & 3.37 \\
5. & Pulambadi & 58.96 & 59 & 76.27 & 16.95 & 93.22 & 3.61 & 0.52 \\
6. & Periyakaruppu Odai & 61.91 & 74 & 72.97 & 20.27 & 93.24 & 3.78 & 0.51 \\
7 & Kalungi & 88.10 & 117 & 82.05 & 13.68 & 95.73 & 4.67 & 0.42 \\
8. & Kottarakkunnu & 186.86 & 240 & 76.25 & 16.67 & 92.92 & 3.75 & 0.55 \\
9. & Solaimatti & 59.59 & 70 & 78.57 & 17.14 & 95.71 & 4.19 & 0.64 \\
10. & Silaiyur & 59.58 & 60 & 81.67 & 11.67 & 93.34 & 4.11 & 0.66 \\
11. & Valaiyur & 28.08 & 30 & 80.00 & 16.67 & 96.67 & 4.90 & 0.43 \\
12. & Chinnar & 72.80 & 76 & 75.00 & 18.42 & 93.42 & 3.86 & 0.69 \\
13. & Koneri & 412.53 & 458 & 73.80 & 18.56 & 92.36 & 3.30 & 0.93 \\
14. & Nakkaselam & 39.04 & 47 & 70.21 & 21.28 & 91.49 & 3.21 & 0.64 \\
15. & Turaiyur Kalathur & 41.58 & 45 & 68.89 & 22.22 & 91.11 & 3.14 & 0.73 \\
16. & Sengattuppatti & 141.54 & 162 & 75.31 & 17.90 & 93.21 & 3.46 & 0.77 \\
17. & Maruvattur & 96.83 & 85 & 69.41 & 21.18 & 90.59 & 2.84 & 0.94 \\
18. & Kanappadi & 131.94 & 151 & 72.85 & 20.53 & 93.38 & 3.37 & 0.72 \\
19. & Shobanapuram & 195.13 & 223 & 74.89 & 18.39 & 93.28 & 3.67 & 0.76 \\
20. & Thalugai & 308.60 & 346 & 72.54 & 19.08 & 91.62 & 4.40 & 0.57 \\
\hline T.S. & & total & & & & & &
\end{tabular}

T.S. no*, total stream number; $R_{\mathrm{b}}{ }^{*}$, bifurcation ratio; $R_{\mathrm{l}}{ }^{*}$, length ratio area and such differences are commonly observed in several other studies (Horton 1945; Mesa 2006). These differences are attributed mainly due to differences in slope and topographic conditions within the watersheds. Among the watersheds of the study area, the mean length ratio is found to range from 0.41 (for Belur watershed) to 3.37 (Gangavalli watershed). The ratio is low $(\leq 0.50)$ in Belur, Kalungi and Valaiyur watersheds and high $(>0.90)$ in Gangavalli, Maruvattur and Koneri watersheds. In rest of the other watersheds it is moderate $(0.51-0.90)$.

\section{Areal aspects}

Areal aspects express the overall plan form and dimensions of drainage basins. The areal aspects considered for the present study include areal extent, length, shape, drainage density, stream frequency and length of overland flow. The procedure adopted for the estimation of these parameters along with the results is discussed in the following section, and the estimations of the areal aspects are presented in Table 3.

\section{Watershed area}

Watershed area is defined as the total area projected upon a horizontal plane and is one of the important morphometrical parameters related to hydrological process. The areal extent of the watersheds of the study area was computed using ArcGIS software and among the watersheds of the study area, it ranges from 14.19 sq. km (Valaiyur watershed) to 159.50 sq. $\mathrm{km}$ (Koneri watershed). Based on the areal extent, the watersheds of the study area were grouped as larger ( $>65$ sq. $\mathrm{km})$, moderate (26-65 sq. km) and smaller ( $\leq 25$ sq. km). In the study area Koneri, Thalugai and Kottarakkannu are larger watersheds whereas Valaiyur, Thuraiyur Kalathur, Nakkasalem, Periyakaruppu Odai and Solaimati watersheds are smaller watersheds. The other watersheds are moderate-sized.

Watershed area has a direct relationship with mean discharge of the watershed/basin (Leopold and Maddock 1953; Strahler 1964; Dunne and Leopold 1978; Zavoianu 1985), mean annual run off (Strahler 1957; Morisawa 1962), and it has an inverse relationship with sediment yield (Strahler 1957) and also with maximum flood discharge per unit area (More 1967 as quoted in Chorley 1969). Based on the above described relationships watershed area has with other hydrological parameters, the mean discharge and mean annual run off are likely to be high in larger watersheds such as Koneri, Thalugai and Kottarakkannu and low in smaller watersheds such as Valaiyur, Thuraiyur Kalathur, Nakkasalem, Periyakaruppu Odai and Solaimati. In rest of the other watersheds they are likely to be moderate. Further, in view of the inverse relationship watershed area has with sediment yield and maximum flood discharge per unit area, smaller watersheds such as Valaiyur, Thuraiyur Kalathur, Nakkasalem, Periyakaruppu Odai and Solaimati are likely to have high sediment yield and maximum flood discharge per unit area, 
Table 3 Areal aspects

\begin{tabular}{llccccccc}
\hline Sl. no. & Watershed name & Area $(\mathrm{sq} . \mathrm{km})$ & $\begin{array}{l}\text { Watershed } \\
\text { length }(\mathrm{km})\end{array}$ & Form factor & DD* & SF* & LOF* & Inf. no.* \\
\hline 1. & Sendarapatti & 27.34 & 7.17 & 0.53 & 2.65 & 3.18 & 0.75 & 8.44 \\
2. & Kallar & 33.49 & 12.24 & 0.22 & 2.97 & 4.06 & 0.67 & 12.05 \\
3. & Belur & 42.90 & 14.16 & 0.21 & 2.54 & 3.64 & 0.79 & 9.24 \\
4. & Gangavalli & 44.73 & 11.55 & 0.34 & 2.58 & 2.75 & 0.78 & 7.09 \\
5. & Pulambadi & 31.05 & 9.21 & 0.37 & 1.90 & 1.90 & 1.05 & 3.61 \\
6. & Periyakaruppu Odai & 21.25 & 8.73 & 0.28 & 2.91 & 3.48 & 0.69 & 10.15 \\
7. & Kalungi & 30.31 & 13.44 & 0.17 & 2.91 & 3.86 & 0.69 & 11.22 \\
8. & Kottarakkannu & 78.98 & 15.40 & 0.33 & 2.37 & 3.04 & 0.85 & 7.19 \\
9. & Solaimatti & 21.68 & 8.69 & 0.29 & 2.75 & 3.23 & 0.73 & 8.87 \\
10. & Silaiyur & 28.66 & 11.60 & 0.21 & 2.08 & 2.09 & 0.96 & 4.35 \\
11. & Valaiyur & 14.19 & 8.08 & 0.22 & 1.98 & 2.11 & 1.01 & 4.18 \\
12. & Chinnar & 29.21 & 10.05 & 0.29 & 2.49 & 2.60 & 0.80 & 6.48 \\
13. & Koneri & 159.50 & 20.30 & 0.39 & 2.59 & 2.87 & 0.77 & 7.43 \\
14. & Nakkaselam & 15.74 & 6.17 & 0.41 & 2.48 & 2.99 & 0.81 & 7.41 \\
15. & Turaiyur Kalathur & 15.59 & 6.25 & 0.40 & 2.67 & 2.89 & 0.75 & 7.70 \\
16. & Sengattuppatti & 45.59 & 11.44 & 0.35 & 3.10 & 3.55 & 0.64 & 11.03 \\
17. & Maruvattur & 45.02 & 10.70 & 0.39 & 2.15 & 1.89 & 0.93 & 4.06 \\
18. & Kanappadi & 51.95 & 12.18 & 0.35 & 2.54 & 2.91 & 0.79 & 7.38 \\
19. & Shobanapuram & 57.33 & 11.92 & 0.40 & 3.40 & 3.89 & 0.59 & 13.24 \\
20. & Thalugai & 103.23 & 15.15 & 0.45 & 2.99 & 3.35 & 0.67 & 10.02 \\
\hline
\end{tabular}

DD*, drainage density (in km/sq. km); $\mathrm{SF}^{*}$, stream frequency (no. streams/sq. km); LOF*, length of overland flow $(\mathrm{km})$; Inf. no*, infiltration number

whereas the larger watersheds such as Koneri, Thalugai and Kottarakkannu are likely to have lower sediment yield and flood discharge per unit area.

\section{Watershed length}

Basin length is the longest length of the basin, from the catchment to the point of confluence (Gregory and Walling 1973) and this measure is essential to estimate the shape, and also the relative relief of the watersheds. The lengths of watersheds of the study area estimated shows that it varies from $6.17 \mathrm{~km}$ (Nakkasalem) to $20.30 \mathrm{~km}$ (Koneri watershed). Koneri, Kottarakunu, Talugai and Belur watersheds are longer $(>14 \mathrm{~km})$, whereas Nakkasalem, Thuraiyur Kalathur, Sendarapatti and Valaiyur are shorter $(\leq 8 \mathrm{~km})$. Length is moderate in rest of the other watersheds.

\section{Basin shape}

Basin shape is the direct outcome of the drainage development in a particular basin. It is evidenced that the basins are pear shaped in early stages and as the erosion cycle advances, the shape becomes more elongated (Padmaja Rao 1978). Form factor $(F)$, suggested by Horton (1932) as an index for determining the shape of the basin has been made use of for the purpose. It is defined as the ratio of the area of the basin to the square of the length of the basin, and according to Horton (1932), the value of ' $F$ ' varies from 0 (for basins with highly elongated shape) to 1 (for a basin with perfect circular shape).

Among the watersheds of the study area the form factor values ranges from 0.17 (Kalungi watershed) to 0.53 (Sendarapatti watershed). Among the watersheds of the study area the estimated form factor value is low $(\leq 0.25)$ in Kalungi, Silaiyur, Belur, Kallar and Valaiyur watersheds, and high $(>0.40)$ in Sendarapatti, Thalugai, Nakkaselam and Shobanapuram watersheds. In rest of the other watersheds it is moderate $(0.26-0.40)$. The form factor values estimated for the watersheds of the study area shows that it ranges from 0.17 (Kalungi watershed) to 0.53 (Sendarapatti watershed) which reflect the elongated shape of all the watersheds, and the variation in form factor values among the watersheds reflects only the degree of elongation of the watersheds.

The shape of the watershed influences the way in which floods are formed and move. It is known that floods are formed and travel more rapidly in a circular watershed which implies that and floods are stronger and have a higher velocity (Zavoianu 1985) in such watersheds. This is due to the fact that in a circular basin run off from various parts of the basin reach the outlet at the same time resulting in a shorter lag time and a higher peak flow (Zavoianu 1985;

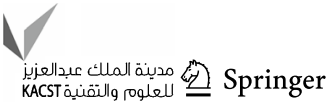


Waugh 1995). In case of elongated basins, the tributaries flow into the main stream at greater intervals of time and space and this broader distribution of flow path lengths and, therefore, a wide range of travel time results in lower peak flow of longer duration. This implies that the flood flows are easier to manage in elongated basins whereas in case of circular basins it is difficult to manage. Though the form factor values clearly reflect the absence of a perfectly circular watershed and hence the absence of any highly flood prone watershed in the study area, it is possible to identify watersheds which are the least, and moderately prone for flash floods. The five watersheds viz., Kalungi, Silaiyur, Belur, Kallar and Valaiyur watersheds which are highly elongated as revealed from their low form factor values are the watersheds least prone for flash flood whereas the five watersheds, viz., Sendarapatti, Thalugai, Nakkaselam, Turaiyur Kalathur and Shobanapuram which are less elongated on account of their relatively higher form factor values are moderately prone for flash floods.

\section{Drainage density}

Drainage density refers to the length of streams within a watershed per unit area (Horton 1932), and among the watersheds of the study area it ranges from 1.90 (Pulambadi watershed) to $3.40 \mathrm{~km} / \mathrm{sq}$. $\mathrm{km}$ (Shobanapuram watershed). It is low $(<2.30 \mathrm{~km} / \mathrm{sq} . \mathrm{km})$ in Pulambadi, Valaiyur, Silaiyur and Maruvattur watersheds, high $(>2.90 \mathrm{~km} / \mathrm{sq} . \mathrm{km})$ in Shobanapuram, Sengattuppatti, Thalugai, Kallar, Periyakaruppu Odai and Kalungi watersheds, and moderate (2.30-2.90 km/ sq. $\mathrm{km}$ ) in rest of the other watersheds.

Drainage density has been used by a number of workers to describe wide ranging characters within a watershed/basin. Studies have shown that drainage density is one of the most sensitive and variable morphometric parameters and it has direct relationship with rainfall intensity (Chorley 1957a, b; Chorley and Morgan 1962), rock resistivity (Zavoianu 1985; Gardiner 1996; Sangireddy et al. 2016), mean annual run off (Morisawa 1962), and an inverse relationship with the degree of development of a drainage net within a basin (Horton 1945), infiltration capacity (Horton 1945; Melton 1957), permeability (Strahler 1956; Zavoianu 1985), vegetation cover (Chorley 1957a, b) and texture of landscape dissection and spacing of streams (Chorley 1969). Drainage density affects the run off pattern, in that a high drainage density removes surface run off rapidly, decreasing the lag time and increasing the peak of the hydrograph (Chorley 1969). From the above described relationship drainage density has with several drainage basin characteristics, it can be inferred that on account of low drainage density, Pulambadi, Valaiyur, Silaiyur and Maruvattur watersheds are likely to have lower rainfall intensity, lower rock resistivity, lower mean annual run off, higher infiltration capacity/permeability, higher vegetation cover and are well drained. On the other hand, in the watersheds of Shobanapuram, Sengattuppatti, Thalugai, Kallar, Periyakaruppu Odai and Kalungi, on account of their high drainage density, the rainfall intensity, rock resistivity and mean annual run off are likely to be high whereas the infiltration capacity/permeability and vegetation cover are likely to be lower, and further these watersheds are less well drained.

\section{Stream frequency}

The stream frequency is the ratio between the total number of stream segments of all orders in a watershed and the basin/watershed area (Horton 1945). It refers to the number of streams per unit area. Estimation of stream frequency value for the watersheds of the study area shows that it ranges from 1.89 (Maruvattur watershed) to 4.06 streams/ sq. km (Kallar watershed). Based on the estimated stream frequency values, the watersheds were grouped as those with low $(<2.5$ streams/sq. km), moderate (2.6-3.5 streams/sq. $\mathrm{km})$ and high stream frequency $(>3.5$ streams $/ \mathrm{sq} . \mathrm{km})$. The analysis of stream frequency values of the watersheds of the study area shows that the stream frequency is low in Maruvattur, Pulambadi, Silaiyur and Valaiyur watersheds and is high in Kallar, Shobanapuram, Kalungi, Belur and Sengattuppatti watersheds.

Stream frequency is directly related to the degree of dissection (Pankaj and Kumar 2009) and run off (Sujata Biswas and Sudhakar Desai 1999), and inversely related to mean annual rainfall (Morisawa 1962). This implies that watersheds with low stream frequency values such as Maruvattur, Pulambadi, Silaiyur and Valaiyur are likely to have higher mean annual rainfall and lower degree of dissection and lower run off. On the other hand watersheds with high stream frequency values such as Kallar, Shobanapuram, Kalungi, Belur and Sengattuppatti are likely to have lower mean annual rainfall and higher degree of dissection and higher run off.

\section{Length of overland flow}

Length of overland flow which is half the reciprocal of drainage density (Horton 1945) is used to describe the length of flow of water over the ground before it becomes concentrated in definite stream channels. Among the watersheds of the study area, it ranges from $0.59 \mathrm{~km}$ (Shobanapuram watershed) to $1.05 \mathrm{~km}$ (Pulambadi watershed). The length of overland flow is shorter $(\leq 0.70 \mathrm{~km})$ in Shobanapuram, Sengattupatti, Talugai, Kallar, Periyakarruppu Odai and Kalungi watersheds, longer ( $>0.90 \mathrm{~km})$ in Pulambadi, Valaiyur, Silaiyur and Maruvattur watersheds, and is moderate in rest of the other watersheds $(0.70-0.90 \mathrm{~km})$. 
In watersheds with shorter length of overland flow values, rain water will enter the stream relatively quickly, and lesser rainfall is sufficient to contribute a significant volume of surface run off to stream discharge. Also this factor has an important control over lag time (Chorley 1969) due to the fact that the mean velocity of the unconcentrated overland flow is less than concentrated channel flow. Smaller values can cause flooding in days of heavy rain, due to the reduced possibility of water infiltration into the soil (Olszevski et al. 2011). From the above inferences, it is evident that in watersheds with shorter length of overland flow values such as Shobanapuram, Sengattupatti, Talugai, Kallar, Periyakarruppu Odai and Kalungi, rain water will enter the stream relatively quickly, and lesser rainfall is sufficient to contribute a significant volume of surface run off to stream discharge, and the lag time will be shorter making them flash flood prone. On the other hand, rain water will take relatively more time to enter into the stream, and hence only in case of higher rainfall there would be significant volume of surface run off to stream discharge in Pulambadi, Valaiyur, Silaiyur and Maruvattur watersheds where the length of overland flow is longer. This implies that the lag time is likely to be longer in these watersheds resulting in lesser flash flood risk in these four watersheds.

\section{Infiltration number}

The infiltration number is the product of drainage density and stream frequency, and it reflects the infiltration potential of a watershed. Lower infiltration numbers indicate higher infiltration and lower run-off (Faniran 1968; Das and Mukherjee 2005; Joji et al. 2013; Elewa et al. 2016). Among the watersheds of the study area, the infiltration number ranges from 3.61 (Pulambadi) to 13.24 (Shobanapuram). Watersheds with lower infiltration number values ( $\leq 6)$ include Pulambadi, Maruvattur, Silaiyur and Valaiyur watersheds and those with higher infiltration number ( $>10$ ) include Shobanapuram, Kallar, Kalungi, Sengattupatti, Periyakarruppu Odai and Thalugai watersheds. In rest of the watersheds it is moderate (7-10). This implies that in watersheds with lower infiltration values such as Pulambadi, Maruvattur, Silaiyur and Valaiyur watersheds infiltration potential is higher. In case of watersheds with higher infiltration number such as Shobanapuram, Kallar, Kalungi, Sengattupatti, Periyakarruppu Odai and Thalugai, infiltration potential is relatively lower.

\section{Relief aspects}

The relief aspects of the drainage basins are related to the study of the three dimensional features of a basin/watershed involving area, volume and attitude of the vertical dimension of landforms. In short, this refers to the vertical component of a drainage basin. The relief aspects considered for the present study include basin relief, relief ratio and ruggedness number.

\section{Relief}

Relief of the watershed is the elevation difference between mouth and the highest point on the watershed perimeter and is expressed in meters. The relief values estimated shows that among the watersheds of the study area, it ranges from $430 \mathrm{~m}$ (Nakkasalem watershed) to $1131 \mathrm{~m}$ (Talugai watershed). The relief is low $(<500 \mathrm{~m})$ in Nakkasalem, Thuraiyur Kalathur, Gangavalli and Pulambadi watersheds, high (> $850 \mathrm{~m}$ ) in Talugai, Shobanapuram, Kottarakunnu and Kalungi watersheds, and moderate (500-850 m) in rest of the other watersheds (Table 4). As relief possesses direct relationship with potential energy (Strahler 1968), denudation rate (Ahnert 1970), amount of sediment that can be transported (Hadley and Schumm 1961) and discharge rate (Mociornita 1964; Diaconu 1966) of a watershed, it is likely that the potential energy, denudation rate, the amount of sediment transported and discharge rate are likely to be higher in watersheds with higher relief such as Talugai, Shobanapuram, Kottarakunnu and Kalungi watersheds and are likely to be low in Nakkasalem, Thuraiyur Kalathur, Gangavalli and Pulambadi watersheds. In rest of the other watersheds these processes are likely to be moderate because of their moderate relief.

\section{Relief ratio}

It is the ratio between the total relief of the basin and its longest dimension parallel to the principal drainage line. For the watersheds of the study area, the estimated relief ratio values vary from 37.29 (Koneri watershed) to 83.31 (Solaimatti watershed). It is high $(>75)$ in Solaimatti, Valaiyur and Thuraiyur Kalathur watersheds, low $(\leq 55)$ in Koneri, Gangavalli and Pulambadi watersheds and is moderate (56-75) in rest of the other watersheds. Relief ratio is an indicator of steepness (Schumm 1956), intensity of erosion process (Chopra et al. 2005; Javed et al. 2009; Ajibade et al. 2010), and also a measure of potential energy available to move water and sediment down slope (Sarkar and Gundekar 2007) and is directly related with all these processes. From the interrelationship relief ratio has with the factors discussed above it is likely that steepness, potential energy and the intensity of erosion process are likely to be high in watersheds with high relief ratio such as Solaimatti, Valaiyur and Thuraiyur Kalathur. Whereas these factors are likely to be low in Koneri, Gangavalli and Pulambadi where the relief ratio values are low, and moderate in other watersheds on account of their moderate relief ratio values. 
Table 4 Relief aspects

\begin{tabular}{|c|c|c|c|c|c|c|c|}
\hline S1. no & Watershed name & $\begin{array}{l}\text { Max. elevation } \\
\text { (in m) }\end{array}$ & $\begin{array}{l}\text { Min. elevation } \\
\text { (in m) }\end{array}$ & Relief (in m) & Relative relief & Relief ratio & Ruggedness no. \\
\hline 1. & Sendarapatti & 781 & 257 & 524 & 22.66 & 73.08 & 0.26 \\
\hline 2. & Kallar & 1021 & 230 & 791 & 23.19 & 64.62 & 0.44 \\
\hline 3. & Belur & 1071 & 225 & 846 & 18.51 & 59.75 & 0.41 \\
\hline 4. & Gangavalli & 660 & 178 & 482 & 15.06 & 41.73 & 0.24 \\
\hline 5. & Pulambadi & 647 & 161 & 486 & 18.75 & 52.77 & 0.17 \\
\hline 6. & Periyakaruppu Odai & 721 & 168 & 553 & 22.79 & 63.34 & 0.31 \\
\hline 7. & Kalungi & 1022 & 169 & 853 & 25.02 & 63.47 & 0.47 \\
\hline 8. & Kottarakkunnu & 1022 & 165 & 857 & 17.97 & 55.65 & 0.38 \\
\hline 9. & Solaimatti & 894 & 170 & 724 & 31.31 & 83.31 & 0.38 \\
\hline 10. & Silaiyur & 930 & 154 & 776 & 25.60 & 66.90 & 0.31 \\
\hline 11. & Valaiyur & 816 & 190 & 626 & 29.61 & 77.48 & 0.23 \\
\hline 12. & Chinnar & 728 & 155 & 573 & 22.23 & 57.01 & 0.27 \\
\hline 13. & Koneri & 887 & 130 & 757 & 11.94 & 37.29 & 0.37 \\
\hline 14. & Nakkaselam & 557 & 127 & 430 & 24.21 & 69.69 & 0.20 \\
\hline 15. & Turaiyur Kalathur & 601 & 130 & 471 & 21.95 & 75.36 & 0.24 \\
\hline 16. & Sengattuppatti & 992 & 155 & 837 & 20.93 & 73.16 & 0.49 \\
\hline 17. & Maruvattur & 900 & 165 & 735 & 23.60 & 68.69 & 0.30 \\
\hline 18. & Kanappadi & 992 & 151 & 841 & 21.56 & 69.05 & 0.40 \\
\hline 19. & Shobanapuram & 1055 & 170 & 885 & 21.35 & 74.24 & 0.57 \\
\hline 20. & Thalugai & 1311 & 180 & 1131 & 19.26 & 74.65 & 0.64 \\
\hline
\end{tabular}

\section{Relative relief}

Relative relief, introduced by Melton (1957) is the ratio between the relief and perimeter of the watershed. It has the advantage over relief ratio in that it is not dependent on the basin length which is questionable parameter in oddly shaped watersheds. For the watersheds of the study area, the estimated relative relief values vary from 11.94 (Koneri watershed) to 31.31 (Solaimatti watershed). The relative relief values are higher $(>25)$ for Solaimatti, Valaiyur, Silaiyur and Kalungi watersheds, lower $(\leq 19)$ for Koneri, Gangavalli, Kottarakunnu, Belur and Pulambadi watersheds, and moderate (20-25) for the rest of the other watersheds.

Relative relief is considered to be the most reliable potential predictor of denudation rates (Ahnert 1970; Summerfield and Hulton 1994; Gunnel 1998). On account of the direct relationship between relative relief and denudation rates, it can be inferred that the denudation rates are likely to be higher in Solaimatti, Valaiyur, Silaiyur and Kalungi watersheds, lower in Koneri, Gangavalli, Kattarakunnu, Belur and Pulambadi watersheds, and moderate in rest of the other watersheds.

\section{Ruggedness number}

Ruggedness number, the product of relief and drainage density is an index which reflects slope steepness and length.
It was estimated using the relationship, Ruggedness Number $=(($ Drainage Density $\times$ Relief $) / 5280)$ as suggested by Hart (1986). The estimated ruggedness number value for the watersheds of the study area ranges from 0.17 (Pulambadi watershed) to 0.64 (Thalugai watershed). The ruggedness number is relatively high $(>0.45)$ in Talugai, Shobanapuram, Sengattupatti and Kalungi watersheds, low $(\leq 0.25)$ in Pulambadi, Nakkasalem, Valaiyur, Gangavalli and Thuraiyur Kalattur watersheds, and moderate $(0.26-0.45)$ in rest of the watersheds.

Extremely high values of the ruggedness number occur when both variables are large, i.e., when slopes are not only steep but long as well (Chow 1964). Further, it is found to be directly proportional to relative peak discharge (Patton 1988). From the relationship ruggedness number possesses with slope and relative peak discharge put forward by Chow (1964), it is likely that the slopes are steep and long, and also the peak discharge is relatively high in Talugai, Shobanapuram, Sengattupatti and Kalungi watersheds, where the estimated ruggedness number value is high, whereas slopes are less steep and lesser in length, and the peak discharge is relatively low in watersheds such as Pulambadi, Nakkasalem, Valaiyur, Gangavalli and Thuraiyur Kalattur where the estimated ruggedness number value is low. In other watersheds, the slope is likely to be moderately steep and of moderate length, and the peak discharge is relatively moderate on account of their moderate ruggedness number. 
The important findings of the study are summarized in the following section:

Most of the watersheds of the study area are either fourth or fifth order watersheds. The trunk stream of the watersheds is found to be medium stream with the exception of Valaiyur watershed where it is a headwater stream. The number of streams decreases with increasing stream order in all the watersheds of the study area. The lower order (first and second order) streams constitute very high proportion (ranging from about 91 to 97\%), of the streams of the watersheds, characteristic of hilly watersheds. The analysis of the proportion of lower order streams of the watersheds shows that Valaiyur, Belur, Kalungi, Solaimatti and Kallar watersheds are characteristic of steeper slopes and quicker water flow, whereas Nakkasalem, Maruvattur, Thuraiyur Kalathur and Talugai watersheds are less steeper with relatively lesser water flow velocity. The distinct variation of bifurcation ratio values among various orders in each watershed, reflects the variations in local physiography and geological conditions within each watershed. The analysis of mean bifurcation ration values of the watersheds shows that the drainage network in all the watersheds of the study area is well developed. It also shows the relatively greater degree of branching, lesser elongation, and higher flash flood potential of Maruvattur, Thuraiyur Kalathur, Nakkasalem, Gangavalli, Koneri, Kanappadi and Sengattupatti watersheds, and lesser degree of branching, greater elongation and lesser flash flood potential of Belur, Valaiyur, Kallar and Kalungi watersheds. The mean annual run off would be higher in Koneri, Thalugai, Shobanapuram and Kottarakkannu watersheds on account of their high total stream lengths, and relatively lower in Valaiyur, Nakkaselam, Thuraiyur Kalathur, Silaiyur, Solaimatti, Pulambadi and Periyakaruppu Odai watersheds on account of their low total stream lengths. In general, it is observed that the mean stream length increases with the stream order in almost all the watersheds.

The analysis of areal extent of the watersheds shows higher mean annual run off, higher mean discharge, lower sediment yield and lower flood discharge per unit area in larger watersheds such as Koneri, Thalugai and Kottarakkannu. Smaller watersheds such as Valaiyur, Thuraiyur Kalathur, Nakkasalem, Periyakaruppu Odai and Solaimati are likely to have lower mean annual run off, lower mean discharge, higher sediment yield and higher flood discharge per unit area. Among the watersheds Koneri, Kottarakunu, Talugai and Belur watersheds are longer whereas Nakkasalem, Thuraiyur Kalathur, Sendarapatti and Valaiyur are shorter. The low drainage density in the watersheds of Pulambadi, Valaiyur, Silaiyur and Maruvattur reflects the lower rainfall intensity, rock resistivity, mean annual run off and higher vegetation cover. In contrast, the high drainage density in the watersheds of Shobanapuram, Sengattuppatti, Thalugai, Kallar, Periyakaruppu Odai and
Kalungi reflects the higher rainfall intensity, rock resistivity, mean annual run off and lower vegetation cover. The analysis the estimated stream frequency values reveals that Maruvattur, Pulambadi, Silaiyur and Valaiyur are likely to have higher mean annual rainfall and lower degree of dissection and lower run off. On the other hand watersheds with high stream frequency values such as Kallar, Shobanapuram, Kalungi, Belur and Sengattuppatti are likely to have lower mean annual rainfall and higher degree of dissection and higher run off. Shorter length of overland flow in Shobanapuram, Sengattupatti, Talugai, Kallar, Periyakarruppu Odai and Kalungi watersheds implies that rain water will enter the stream relatively quickly, and lesser rainfall is sufficient to contribute a significant volume of surface run off to stream discharge, and the lag time will be shorter making them flash flood prone. In case of watersheds with longer length of overland flow such as Pulambadi, Valaiyur, Silaiyur and Maruvattur watersheds rain water will take relatively more time to enter into the stream, and hence only in case of higher rainfall there would be significant volume of surface run off to stream discharge. Longer lag time in these watersheds implies easier flood management. The analysis of infiltration number reveals that infiltration potential is higher in Pulambadi, Maruvattur, Silaiyur and Valaiyur watersheds on account of lower infiltration number values. On the otherhand it is lower in Shobanapuram, Kallar, Kalungi, Sengattupatti, Periyakarruppu Odai and Thalugai watersheds in view of higher infiltration number.

The analysis of the estimated relief of the watersheds reveal that potential energy, denudation rate, the amount of sediment transported and discharge rate are likely to be higher in watersheds with higher relief such as Talugai, Shobanapuram, Kottarakunnu and Kalungi watersheds and are likely to be low in Nakkasalem, Thuraiyur Kalathur, Gangavalli and Pulambadi watersheds. The analysis of the relief ratio values of the watersheds reflects the steeper terrain condition, higher potential energy and intensity of erosion in watersheds with high relief ratio such as Solaimatti, Valaiyur and Thuraiyur Kalathur. However, the lower relief ratio values of Koneri, Gangavalli and Pulambadi watersheds reflect lesser steepness, and lesser potential energy and intensity of erosion. The higher relative relief values reflects higher denudation rates in Solaimatti, Valaiyur, Silaiyur and Kalungi watersheds whereas it is lower in Koneri, Gangavalli, Kottarakunnu, Belur and Pulambadi watersheds on account of lower relative relief values. The estimated higher ruggedness number values for Talugai, Shobanapuram, Sengattupatti and Kalungi watersheds reveal that the slopes are not only steep but also long, and further the peak discharge is relatively high these watersheds. In case of watersheds with lower ruggedness number such as Pulambadi, Nakkasalem, Valaiyur, Gangavalli and Thuraiyur Kalattur the slopes are

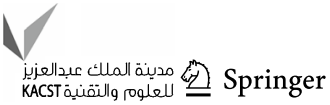


less steep and lesser in length, and further the peak discharge is relatively low.

\section{Conclusion}

The present study has helped to decipher information relating to the form, geomorphic and hydrologic processes of the 20 watersheds of the Pachamalai hills and its adjoinings. Besides this, understanding the variations of these form and processes among the watersheds of the study can serve as essential input towards prioritizing the watersheds for formulating effective strategies towards the land and water management of this important resource-rich hill of the region.

Open Access This article is distributed under the terms of the Creative Commons Attribution 4.0 International License (http://creativeco mmons.org/licenses/by/4.0/), which permits unrestricted use, distribution, and reproduction in any medium, provided you give appropriate credit to the original author(s) and the source, provide a link to the Creative Commons license, and indicate if changes were made.

\section{References}

Ahnert F (1970) Functional relationships between denudation, relief and uplift in large mid-latitude drainage basins. Am J Sci 268:243-263

Ajibade LT, Ifabiyi IP, Iroye KA, Ogunteru S (2010) Morphometric analysis of Ogunpa and Ogbere drainage basins, Ibadan, Nigeria. Ethiop J Environ Stud Manag 3(1):13-19

Bartlett JM, Harris NBW, Hawkesworth CJ, Santosh M (1995) New isotope constraints on the crustal evolution of South India and Pan-African granulite metamorphism. Mem Geol Soc India 34:391-397

Chetty TRK, Bhaskara Rao YJ (2006) Constrictive deformation in transpressional regime, field evidence from the Cauvery Shear Zone, Southern Granulite Terrain, India. J Struct Geol 28:713-720

Chopra R, Dhiman RD, Sharma PK (2005) Morphometric analysis of sub-Watersheds in Gurdaspur District, Punjab using remote sensing and GIS techniques. J Indian Soc Remote Sens 33(4):531-539

Chorley RJ (1957a) Climate and morphometry. J Geol 65:628-638

Chorley RJ (1957b) Climate and geomorphology. J Geol 65(6):628-638

Chorley RJ (1969) The drainage basin as the fundamental geomorphic unit. In: Chorley RJ (ed) Introduction to fluvial processes. Methuen Co. Ltd, London, pp 30-52

Chorley RJ, Morgan MA (1962) Comparison of morphometric features, Unaka Mountains, Tennessee and North Carolina, and Dartmoor, England. Geol Soc Am Bull 73:17-34

Chow VT (1964) Handbook of hydrology. McGraw-Hill Book Co. Inc, New York

Das AK, Mukherjee S (2005) Drainage morphometry using satellite data and GIS in Raigad District, Maharashtra. J Geol Soc India 65:577-586

Diaconu C (1966) Altitude, one of the basic criteria for organizing hydrometeorological networks in mountainous regions. Studii de Hidrologie 18:41-55 (in Romanian)
Doornkamp J (1968) The analysis of morphometric properties of drainage basins by the Spearman's Rank Correlation Technique. In: Slaymaker HO (ed) Morphometric analysis of maps, British Geomorphol Res Group Occassional Paper 4, pp 31-40

Doornkamp JC, King CAM (1971) Numerical analysis in geomorphology - an introduction. Macmillan and Co. Ltd, London, p 372

Drury SA, Holt RW (1980) The tectonic framework of South Indian craton: a reconnaissance involving landsat imagery. Tectonophysics $65: 1-15$

Dunne T, Leopold LB (1978) Water in environmental planning. W.H. Freeman Co., San Francisco, p 818

Elewa HH, Ramadan EM, Nosair AM (2016) Spatial-based hydromorphometric watershed modeling for the assessment of flooding potentialities. Environ Earth Sci 75:906-927. https://doi. org/10.1007/s12665-016-5692-4

Faniran A (1968) The index of drainage intensity - a provisional new drainage factor. Aus J Sci 31:328-330

Gardiner V (1975) Drainage basin morphometry. British Geomorphological Research Group, Technical Bull, vol 14. p 48

Gardiner V (1996) Channel networks: progress in the study of spatial and temporal variations of drainage density. In: Gurnell A, Petts GE (eds) Changing river channels. Wiley, New York, pp 65-85

Geetha Rani M (2010) Medicinal plants viz a viz indigenous knowledge among the tribals of Pachamalai hills. Ind J Trad Knowl 9(1):209-215

Gregory KJ, Walling DE (1973) Drainage basin form and process-a geomorphological approach. Edward Arnold Pub. Ltd., London, p 321

Gunnel Y (1998) Present, past and potential denudation rates: is there a link? Tentative evidence from fission-track data, river sediment loads and terrain analysis in the South Indian shield. Geomorphology 25:135-153

Hadley RF, Schumm SA (1961) Sediment sources and drainage basin characteristics in upper Cheyenne River Basin. U.S. Geological Survey Water-Supply, Paper 1531-B. p 198

Hart MG (1986) Geomorphology—pure and applied. Allen and Unwin Pub. Ltd., London, p 211

Horton RE (1932) Drainage basin characteristics. Trans Am Geophys Uni 13:350-361

Horton RE (1945) Erosional development of streams and their drainage basins: hydrophysical approach to quantitative morphology. Bull Geol Soc Am 56:275-370

Javed A, Khanday MY, Ahmed R (2009) Prioritisation of sub-watersheds based on morphometric and land use analysis using remote sensing and GIS techniques. J Ind Soc Remote Sens 37:261-274

Jayananda M, Janardhan AS, Sivasubramanian P, Peucat JJ (1995) Geochronologic and Isotopic constraints on granulite formation in the Kodaikkanal area, Southern India. Mem Geol Soc India 34:373-390

Joji VS, Nair ASK, Baiju KV (2013) Drainage basin delineation and quantitative analysis of Panamaram watershed of Kabani River Basin, Kerala using remote sensing and GIS. J Geol Soc India 82:368-378

Langbein WB (1947) Topographic characteristics of drainage Basins. U.S. Geol Sur Water Supp Paper 968-C

Leopold LB, Maddock T (1953) The hydraulic geometry of stream channels and some physiographic implications. USGS Profess Paper 252. p 57

Leopold LB, Miller JP (1956) Ephemeral streams: hydraulic factors and their relation to the drainage network. U.S. Geol Sur Profess Paper 282 A, Washington, D.C. pp 1-37

Mathew KM (1981) Materials for a flora of the Tamil Nadu carnatic. The Rapinat Herbarium, St. Joseph's College, Tiruchirappalli, p 465

Melton MA (1957) An analysis of the relations among elements of climate, surface, properties and geomorphology. Project NR 389-042 
Technical Report 11. Columbia University, Department of Geology, ONR, Geography Branch, New York

Mesa LM (2006) Morphometric analysis of a subtropical Andean basin (Tucuman, Argentina). Environ Geol 50(8):1235-1242. https:// doi.org/10.1007/s00254-006-0297-y

Miller VC (1953) A quantitative geomorphic study of drainage basin characteristics in the Clinch Mountain Area, Virginia and Tennessee, Dept. of Geology, Columbia University, Contract N6 ONR 271-30, Technical Report 3, pp 1-30. America Bull 69: 279-300

Mociornita C (1964) Some results for maximum rainfall discharge by Romania's rivers. Studii de Hidrologie 11:35-48 (in Romanian)

More RJ (1967) Hydrological models and geography. In: Chorley RJ, Hagget $\mathrm{P}$ (eds) Models in geography. Methuen Publishers, London, pp 45-85

Morisawa ME (1959) Relation of quantitative geomorphology of stream flow in representative watersheds of the Appalachian Plateau Province, Columbia University, Office of Naval Research, Project NR 389-042, Technical Report 20

Morisawa ME (1962) Quantitative Geomorphology of some watersheds in the Appalachian Plateau. Geol Soc Am Bull 73:1025-1046

Olszevski N, Filho EIF, Costa LMDA, Schaefer CEGR, Souza EDE, Costa ODV (2011) Morphology and hydrological aspects of Black River Basin, division of state of Rio de Janeiro and Minas Gerais. Braz J For Sci 35:485-492

Padmaja Rao G (1978) Some morphometric techniques with relation to discharge of Musi River Basin, Andhra Pradesh. In: Symposium on morphology and evolution of landform, Dept. of Geology, University of Delhi, New Delhi

Pankaj A, Kumar Pankaj (2009) GIS-based morphometric analysis of five major sub-watersheds of Song River, Dehradun District, Uttarakhand with special reference to landslide incidences. J Ind Soc Remote Sens 37(1):157-166

Patton PC (1988) Drainage basin morphometry and floods. In: Baker VR, Kochel RC, Patton PC (eds) Flood geomorphology. Wiley Interscience Publishers, New York, p 503

Pragasan AL (2014) Assessment of aboveground biomass stock in the Pachaimalai forest of Eastern Ghats in India. Appl Ecol Environ Res 13(1):133-145. https://doi.org/10.15666/aeer/1301_133145

Ramasamy SM, Balaji S, Kumanan CJ (1999) Tectonic evolution of early Precambrian South Indian shield using remote sensing data. J Ind Soc Remote Sens 27(2):91-104

Rudraiah M, Govindaiah S, Vittala S (2008) Morphometry using remote sensing and GIS techniques in the sub-basins of Kagna River Basin, Gulburga District, Karnataka, India. J Ind Soc Remote Sens 36:351-360

Sangireddy H, Carothers RA, Stark CP, Passalacqua P (2016) Controls of climate, topography, vegetation, and lithology on drainage density extracted from high resolution topography data. J Hydrol 537:271-282

Sarkar S, Gundekar HG, (2007) Geomorphological parameters: are they indicators for installation of a hydropower site? In: Proc. international conference on small hydropower-Hydro Sri Lanka. pp 22-24
Scheidegger AE (1967) On the topology of river nets. Water Resour Res 3(1):103-106

Schumm SA (1956) The evolution of drainage systems and slopes in badlands at Perth Amboy, New Jersey. Geol Soc Am Bull 67:597-646

Shreve RL (1966) Statistical law of stream numbers. J Geol 74(1):17-37

Srinivasan BV (2006) Geology and mineral resources of the states of India: Tamil Nadu and Pondicherry, Geological Survey of India Miscellaneous Publication No. 30, G.S.I, Chennai. p 71

Strahler AN (1952) Dynamic basis of geomorphology. Geol Soc Am Bull 63:923-938

Strahler AN (1956) Quantitative slope analysis. Geol Soc Am Bull 67(5):571-596. https://doi. org/10.1130/0016-7606(1956)67[571:QSA]2.0.CO;2

Strahler AN (1957) Quantitative analysis of watershed geomorphology. Trans Am Geophys Union 38(6):913-920

Strahler AN (1964) Quantitative geomorphology of drainage basins and channel networks. In: Handbook

Strahler AN (1968) Quantitative geomorphology. In: Fairbridge RW (ed) The encyclopedia of geomorphology. Reinhold Book Crop, New York

Sujata Biswas S, Sudhakar Desai VR (1999) Prioritisation of subwatersheds based on morphometric analysis of drainage basin: a remote sensing and GIS approach. J Ind Soc Remote Sens 27(3):155-166

Summerfield MA, Hulton NJ (1994) Natural controls of fluvial denudation rates in major world drainage basins. J Geophys Res 99:13871-13883

Unnikrishnan Warrier C, Santosh M, Yoshida M (1995) First Report of Pan-African $\mathrm{Sm}-\mathrm{Nd}$ and $\mathrm{Rb}-\mathrm{Sr}$ mineral isochron ages from regional charnockites of Southern India. Geol Mag 132(3):253-260

Velmani KSK (1998) Gazetteers of Tamil Nadu, Tiruchirappalli District, vol I. The Department of Archives and Historical Research, Government of Tamil Nadu, Tiruchirappalli, pp 1-877

Velmani KSK (1999) Gazetteers of Tamil Nadu, Tiruchirappalli District, vol II. The Department of Archives and Historical Research, Government of Tamil Nadu, Tiruchirappalli, pp 878-1644

Vittala SS, Govindaiah S, Gowda HH (2004) Morphometric analysis of sub-watersheds in the Pavagada Area of Tumkur District, South India using remote sensing a GIS techniques. J Ind Soc Remote Sens 32(4):351-362

Waugh D (1995) Geography, an integrated approach, chapter-3: morphometry of drainage basins, 2nd edn. Nelson Pub, New York

Zavoianu I (1985) Morphometry of drainage basins. Elsevier, Amsterdam, p 238

Publisher's Note Springer Nature remains neutral with regard to jurisdictional claims in published maps and institutional affiliations. 